原 著

\title{
側頭葉てんかんに抢け·る一側限局性発射による複雑部分発作
}

\section{Complex Partial Seizures with Unilateral Discharges Originating from Temporal Lobe}

$$
\begin{aligned}
& \text { 須 江 洋 成*,** 日 吉 俊 雄 }{ }^{*} \text { 三 原 忠 紘* } \\
& \text { 松田一 已* 鳥取孝 安* 岸信 之,*** } \\
& \text { 渡辺裕貴公木和-**清野昌一* }
\end{aligned}
$$

要旨 : 難治側頭葉てんかんの外科治療の術前評価のために行った長時間頭蓋内脳波記録に ついて，24症例，計 123 回の複雑部分発作の脳波・発作症状相関を検討した。側頭葉起源 の複雑部分発作は，1）自己維持性の律動性発作発射が起源側の側頭葉にとどまる一側性 複雑部分発作と，2）対側半球の側頭葉に伝播する両側化複雑部分発作に二分することが できた，意識減損時の発作発射は必ずしも両側側頭葉を巻き込むことを必要としない。し かし, 焦点側側頭葉の内側構造（海馬, 扁桃核）と外側皮質はともに発作発射に巻き込ま れていた。一側性と両側化複雑部分発作の臨床症状を比較すると, 前発作では外来刺激化 対する反応性が部分的に保たれ，意識減損からの回復は速やかである傾向がみられ，反応 性の变夫によって特徴づけられる無動・凝視状態は認められなかった。複雑部分発作の意 識減損にかかわる側頭葉と脳幹の機能関連について考察を加えた。

てんかん研究 $1991 ; 9: 54-62$

Key Words: temporal lobe epilepsy, complex partial seizures, anatomo-electro-clinical correlation, unilateral discharges, motionless staring.

（受付：1990年12月 1 日，受理：1991年 1 月14日）

\section{はじめに}

意識減損を伴う部分起始性のてんかん発作は, 複雑部分発作と定義される ${ }^{1)}$ 。複雑部分発作時の 意識減損は, 一側側頭葉のてんかん焦点から起始 した発作発射が対側側頭葉に伝播した結果生ずる と考兄らているが, 発作時の脳波像, 特に頭蓋 内脳波所見と意識減損との関連をとりあげた報告 は少ない(5,14 16)。そこで, 難治の側頭葉てんかん の外科治療の術前評価のために長時間頭蓋内脳波
記録を行った症例を対象に, 複雑部分発作時脳波 像を検討した。その結果, 自己維持性の発作発射 が一側の側頭葉にとどまる複雑部分発作の存在が 確かめられた。その発作時脳波所見亡臨床発作症 状との相関を検討した。

\section{対象と方法}

難治側頭葉てんかんの外科治療のために長時間 頭蓋内脳波記録を受けた計24症例（男15例，女 9 例）を対象とした。患者の年齢は15～40歳（平均

* 国立療盖所静岡東病院（てんかんセンター）

[干420 静岡市漆山 886]

Hironari Sue, Toshio Hiyoshi, Tadahiro Mihara, Kazumi Matsuda, Takayasu Tottori, Nobuyuki Kishi, Yutaka Watanabe, Kazuichi Yagi, Masakazu Seino

National Epilepsy Center, Shizuoka Higashi Hospital

** 現 東京慈恵会医科大学精神医学教室 $\quad * * *$ 現 公立豊岡病院精神科 
26. 1 歳)，てんかんの罹病期間は 1 34 年 (平均 12.9 年), 複雑部分発作の 頻度は 1 例を除く全例が週に 1 回以上 であった。また全例に, 総頸動脈内ア ミタール・テスト ${ }^{18)}$ を行い, 言語優位 側は左側 22 例, 右側 1 例であり, 残る 1 例は両側性と判定された(Table 1)。 頭蓋内脳波記録の方法を概略する。 両側海馬と扁桃核に脳内深部電極を, 側頭葉底部に硬膜下電極を留置し，さ らに手術適応を決める術前評価の第一 段階で, てんかん原性焦点が推測され た側の眼窩・前頭回と海馬旁回に深部 電極を, 前側頭葉, 側頭 - 後頭葉, 側 頭・頭頂葉, あるいは側頭・前頭葉に 3〜 4 本の硬膜下電極を留置した ${ }^{11 ~ 13) 。 ~}$ 電極植兄达及手術の約 1 週間後より, テレメータによる約 2 週間の連続脳波 記録を行った。この間症例によって は, 血中濃度測定の下に抗てんかん薬 を慎重に泍減し，自発性の複雑部分発 作を 3 回以上記録するようにつとめ た。このようにして脳波・発作同時記 録装置に記録された発作のらち，発作 時の臨床症状と脳波所見の関連を十分 に検討しえた計 123 回の複雑部分発作 そついて, 自己維持性の律動性発射の 起始部位および意識減損の経過と発作 発射の伝播様態との関連を検討した。

発作発射の起始部位は, 臨床発作症 状の始まりょりも先行し，あるいはそれと同時 に, 自己維持性の速い棘波律動が出現した頭蓋内 誘導部位をさし，これが右側側頭葉か，左側か (laterality，側方性)，扁桃核・海馬を含む内側構 造か，外側皮質か (focality，局在性）を検討した。 同一症例について複数の発作が記録された場合に は，(1) てんかん発射が同一部位から起始し, （2）この発作に関連して臨床発作症状が生起し, （3）その発作表出が固有発作 (habitual seizure) と同じである，以上の条件をそなえた場合，その 部位をてんかん原性焦点と定めた。その側方性 は, 15例（88発作）が右側, 9 例 (35発作) は左
Table 1 Sex and age of 24 patients, number of documented complex partial seizures, side of discharge origin and speech dominance

\begin{tabular}{|c|c|c|c|c|c|c|}
\hline \multirow{2}{*}{ case no. } & \multirow{2}{*}{$\operatorname{sex}$} & \multirow{2}{*}{ age } & \multicolumn{2}{|c|}{ no. of seizures } & \multirow{2}{*}{$\begin{array}{l}\text { side of } \\
\text { discharge } \\
\text { origin }\end{array}$} & \multirow{2}{*}{$\begin{array}{l}\text { speech } \\
\text { dominance }\end{array}$} \\
\hline & & & Uni. & Bi. & & \\
\hline 1 & $\mathrm{~m}$ & 26 & 0 & 5 & $\mathbf{R}$ & $\mathrm{L}$ \\
\hline 2 & $\mathrm{~m}$ & 26 & 1 & 1 & $\mathrm{R}$ & $\mathbf{L}$ \\
\hline 3 & $\mathrm{~m}$ & 24 & 0 & 2 & $\mathrm{~L}$ & $\mathrm{~L}$ \\
\hline 4 & $\mathrm{~m}$ & 25 & 0 & 2 & $\mathrm{R}$ & $\mathrm{L}$ \\
\hline 5 & $\mathrm{~m}$ & 26 & 0 & 2 & $\mathrm{~L}$ & $\mathbf{L}$ \\
\hline 6 & $\mathrm{~m}$ & 24 & 1 & 2 & L & $\mathbf{L}$ \\
\hline 7 & $\mathrm{f}$ & 21 & 0 & 4 & $\mathrm{R}$ & $\mathrm{L}$ \\
\hline 8 & $\mathrm{~m}$ & 33 & 0 & 4 & $\mathrm{~L}$ & $\mathbf{R}$ \\
\hline 9 & f & 25 & 0 & 7 & $\mathrm{~L}$ & $\mathrm{~L}$ \\
\hline 10 & $\mathrm{~m}$ & 36 & 0 & 2 & $\mathrm{R}$ & $\mathbf{L}$ \\
\hline 11 & $\mathrm{~m}$ & 29 & 0 & 7 & $\mathrm{~L}$ & $\mathbf{L}$ \\
\hline 12 & $f$ & 27 & 0 & 5 & $\mathrm{R}$ & $\mathrm{L}$ \\
\hline 13 & $f$ & 19 & 0 & 1 & $\mathrm{~L}$ & B \\
\hline 14 & $\mathrm{~m}$ & 40 & 4 & 0 & $\mathrm{R}$ & $\mathrm{L}$ \\
\hline 15 & $f$ & 26 & 3 & 0 & $\mathrm{R}$ & $\mathbf{L}$ \\
\hline 16 & $f$ & 23 & 0 & 7 & $\mathrm{R}$ & $\mathbf{L}$ \\
\hline 17 & $\mathrm{~m}$ & 26 & 0 & 8 & $\mathrm{R}$ & $\mathrm{L}$ \\
\hline 18 & $\mathrm{~m}$ & 35 & 1 & 7 & $\mathbf{L}$ & $\mathrm{L}$ \\
\hline 19 & $\mathrm{~m}$ & 25 & 0 & 2 & $\mathrm{R}$ & L \\
\hline 20 & $\mathrm{~m}$ & 21 & 8 & 0 & $\mathrm{R}$ & L \\
\hline 21 & $f$ & 18 & 2 & 20 & $\mathrm{R}$ & $\mathrm{L}$ \\
\hline 22 & $f$ & 39 & 0 & 1 & $\mathbf{L}$ & $\mathbf{L}$ \\
\hline 23 & $\mathrm{f}$ & 15 & 4 & 0 & $\mathrm{R}$ & $\mathbf{L}$ \\
\hline 24 & $\mathrm{~m}$ & 17 & 10 & 0 & $\mathrm{R}$ & $\mathbf{L}$ \\
\hline
\end{tabular}

Abbreviations: m, male; f, female; Uni./Bi., seizures accompaning unilateral/bilateral discharges; $R$, right; $L$, left and $\mathrm{B}$, bilateral
側であり，局在性は，15例（79発作）が側頭葉内 側, 9 例 (44 発作) は外側皮質であった（Table 2)。

意識減損の判定は, 外来刺激に対する反応性 (responsiveness) 打よびもしくは自覚性 (awareness) 抢よび発作中の出来事に対する健忘 (amnesia）にもとづいて判定した。すなわち，単純な指 示・問い掛けに対して言語性・非言語性の応答が できるか，あるいは意志にもとづく自発運動を起 こしえるか，または発作中の出来事をどれほど想 起できるか否かを発作観察記録ならびにテープを 再生して検討した。な特, 明らかな発作性失語, 
Table 2 Number of patients (seizures) in relation to the side/site of their seizure origin

\begin{tabular}{l|r|r|r}
\hline \multirow{2}{*}{} & \multicolumn{2}{|c|}{ site } & total \\
\cline { 2 - 4 } & \multicolumn{1}{|c|}{ mesial } & lateral & \\
\hline left & $5(14)$ & $4(21)$ & $9(35)$ \\
right & $10(65)$ & $5(23)$ & $15(88)$ \\
total & $15(79)$ & $9(44)$ & $24(123)$ \\
\hline
\end{tabular}

失行, 失認を呈した症例はなく，また二次性全般 化痙攣に進展した発作は対象から除外した。

\section{結＼cjkstart果}

\section{1. 発射の伝播様式}

\section{1）発作発射の伝播梯式と意識減損の推移}

一側側頭葉に起始した発作発射が，対側側頭葉 に伝播するか否かに注目して脳波像を観察したと ころ, 複雑部分発作は，（1）対側側頭葉に発作発 射が伝播する両側化複雑部分発作と，(2) 発作発 射が起始側側頭葉にとどまり，対側側頭葉に自己 維持性の律動性てんかん発射が認められない一側 性複雑部分発作に二分することができた。それぞ れの代表的な深部脳波と意識減損の推移を呈示す る。

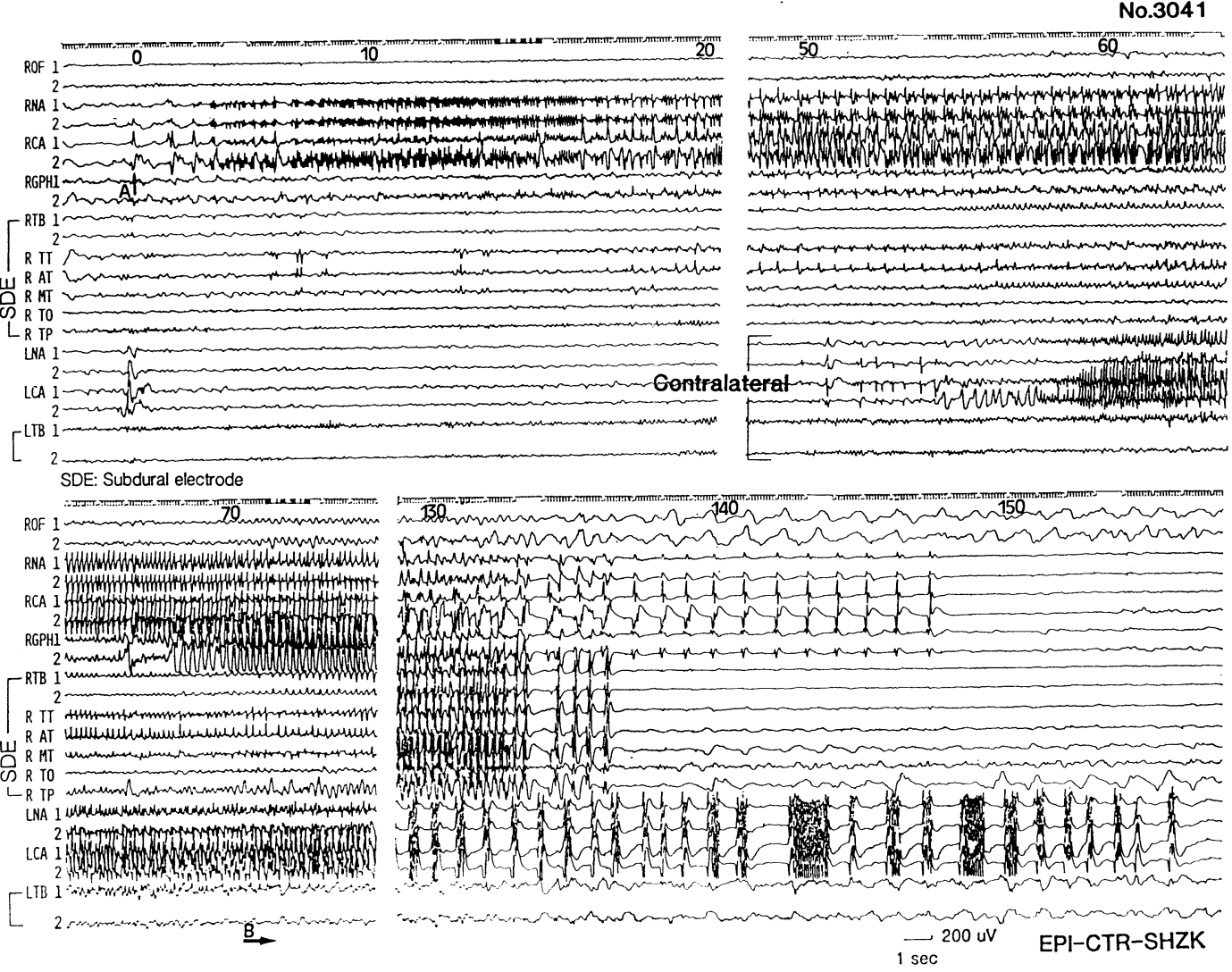

Fig. 1 Intracranial EEGs of a complex partial seizure accompaning bilateral discharges

Depth electrodes implanted into: nucleus amygdaloideus (NA), cornu ammonis (CA), gyrus parahippocampi (GPH) and orbito-frontal gyrus (OF). Subdural electrodes placed on: temporo-basal (TB), anterior temporal (AT), middle temporal (MT), temporal tip (TT), temporo-parietal (TP) and temporooccipital (TO) areas. Other abbreviations: L, left; R, right; SDE, subdural electrodes; A, initiation of ictal discharges; B, initiation of impairment of consciousness. 


\section{a. 両側化複雑部分発作}

23歳, 女性（No. 3041）, 胸のあたりの不快感 を自覚した後に意識が減損し，一点を凝視しつつ わずかな自動症を呈する発作を反復する。右側の 海馬 (R cornu ammonis, RCA) 飞高振幅の棘波 が出現し [A]，これにわずかに遅れて右扁桃核 (R nucleus amygdaloideus, RNA) にこれよりも 低振幅の棘波律動の出現をみる (Fig. 1)。この RCA，RNA に見られる棘波は周波数を増して群 発し自己維持性の発作発射を形成する。この発射 は右海馬旁回(R gyrus parahippocampi, RGPH) に拡延し，15秒を過ぎると， RCA と RNA の棘 波律動に徐波が插入されはじめる。同側外側皮質 に接する硬膜下誘導部位 RTT (R temporal tip), RAT ( R anterior temporal area) では最初は散 発性に, やがて律動性かつ同期性に棘波が出現し はじめる。50秒を過ぎると対側の左海馬 (LCA) と扁桃核 (LNA) 飞棘波がはじめは散発性につい で連続して出現し自己維持性の棘波律動を形成す る。また, 右側側頭葉内側の硬膜下誘導部位であ る RTB (R temporo-basal area)。さらに同側側 頭葉外側の硬膜下誘導部位 RMT ( $\mathrm{R}$ middle temporal area), RTP (R temporo-parietal area) にも速波が散発しはじめる。60秒を過ぎると両側 の側頭葉内側構造すなわち RCA，RNA，LCA， LNA がともに発火するようになり，ついで右側 外側皮質全体が高振幅棘波律動に巻き込まれ， 135秒後に急に平坦化する。148秒にはそれまで発 火頻度を減じてきた右側内側構造の発作発射は止 み平坦化する。左側内側構造の発火はこれょり遅 れて, 155 秒後に平坦化する。この両側化複雑部 分発作の発作発射は完全に消失するまでに, 脳波 上の発作起始から 155 秒を要した。

以上の脳波像に対応する臨床発作症状はつぎの ようである。座位にある患者は発作発射が始まっ てから 9 秒後に胸部不快感の信号症状を感じて, 検者を呼ぶコール・ボタンを規則正しく押し始め る。18秒後に 1 度ボタン押しの間隔が乱れる。次 第にその間隔は不規則となり，59秒以後には間延 びが目立つようになり，71秒でボタン押しが途絶 える [B]。この時, ‘視線の動きが止まり, 僅か に前かがみの姿勢となる。呼名に反応しない。無
動, 無反応の状態となる。96秒より, 体を起こし 座り直すようなしぐさを示す，無目的に足をゆっ くりと動かすなどのわずかな動きが見られるよう になる。130 秒以後にはそれまで止まっていた視 線の動きが見られ，両足を大きく動かす。156 秒 ではじめて検者に視線を向け，間もなく呼び掛け に反応が見られた。以上の発作間の出来事を一切 想起できない。

b. 一側性複雑部分発作

15歳, 女性 (No. 11908), 名状乙難い信号症状 から意識減損に至るか, あるいは最初から意識減 損にはじまり自動症を呈する発作を反復する。

右側側頭前部の硬膜下電極 RAT 飞鋭波が連続 して出現しはじめ [A], 右側側頭底部 (RTB), さらに右側頭・頭頂葉 (RTP), 側頭 - 前頭葉 $(R$ temporo-frontal area, RTF) へと拡延する (Fig. 2)。この時点まで, 右扁桃核 (RNA), 右海馬 (RCA)，右海馬旁回 (RGPH) には発射は全くみ られず，約 20 秒を過ぎて約 $4 \mathrm{~Hz}$ の徐波律動が出 現しはじめる。硬膜下誘導 RAT, RTB, さらに RTP, RTF, RTO (R temporo-occipital area) の鋭波が高振幅の棘波律動に転ずると， RNA， RCA， RGPH の徐波律動は低振幅化し, かつ 6 $\mathrm{Hz}$ と速くなり，律動性を増して速い棘波律動を 形成する。この約 $6 \mathrm{~Hz}$ の律動波は硬膜下誘導に ほぼ同期して出現し，85秒後にすべての発射は急 に平坦化する。しかし，対側の海馬，扁桃核およ び硬膜下誘導部位 (LTB) には, 発作発射がはじ まってから 32 秒後までは $3 \sim 4 \mathrm{~Hz}$ の徐波活動を 呈し, それ以後に約 $6 \mathrm{~Hz}$ の徐波活動が混入する が，棘波は全くみられない。

以上の脳波像に対応する発作症状はつぎのよう である。ベッドに臥位のところ発作発射の始まり から29秒遅れて，シーツをまさぐるしぐさが見ら れるが，これに一致して視線の動きは少なくな りまばたきはそしい[B]。自発的な体の動きは わずかに見られる。38秒後に頭を起こすが呼びか けに反応しない。51秒後の呼名に対して一切の応 答はない。92秒後に大きな動きが見られ，ベッド に横になり，呼び掛けた検者とはじめて視線を合 わす。 


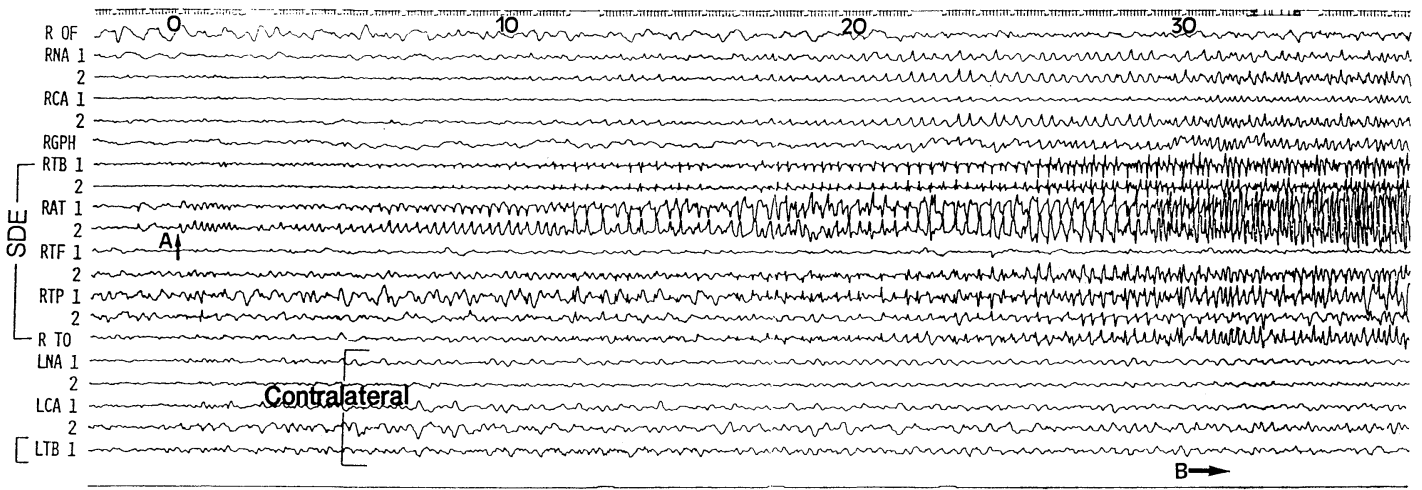

SDE: Subdural electrode

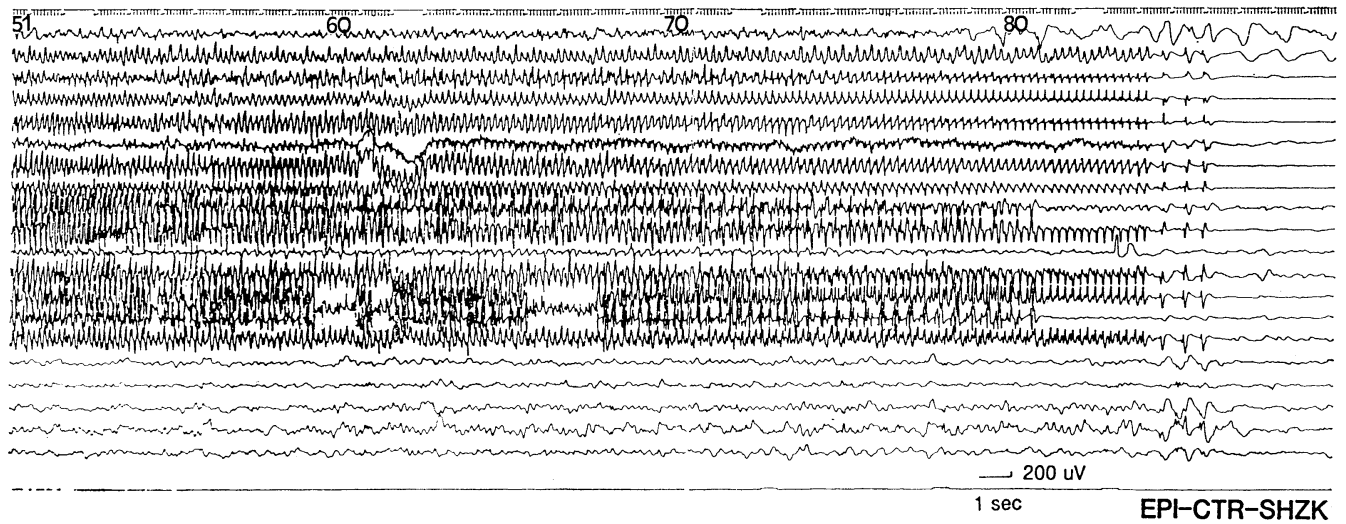

Fig. 2 Intracranial EEGs of a complex partial seizure accompaning unilateral discharges

Abbreviation: TF, subdural electrodes placed on temporo-frontal area. Other abbreviations are the same as in Fig. 1.

\section{2）発作発射の伝播様式からみた意識減損}

計 123 回の複雑部分発作を発作発射の様式から 二分すると， 89 発作 $(72 \%)$ が両側化複雑部分発 作, 34発作 $(28 \%)$ が一側性複雑部分発作であっ た。そこで個々の症例のすべての発作について, 両側化発作か，一側性発作か，あるいはこの二つ の伝播様式が共存しているかを検討した。その結 果, 15症例では59回の発作はすべて両側化発作で ありここれらの症例を両側化群とした。また 5 症 例では29回の発作はすべて一側性発作であり，こ れを一側性群とした。残る 4 例では，両側化発作 と一側性発作が共存し, これを混合群とした。そ の内容は30回の両側化発作と 5 回の一側性発作で あった。

これら 3 群の焦点部位の側方性をみると, 両側 化群では左側が 7 例（局在性は内側 4 例, 外側 3
例)，右側が 8 例（内側 6 例，外側 2 例)，一側性 群では右側のみ 5 例（内側 2 例，外側 3 例), 混 合群では左側（内側 1 例，外側 1 例), 右側（内 側の夕 2 例）ともに 2 例であった (Table 3)。

3）意識減損時の頭蓋内脳波像一一側性 ならび

\section{に両側化発作の比較一}

臨床的に意識減損が検出できた時点の頭蓋内脳 波対応をみると，第 1 例の B 点 (Fig. 1)，第 2 例 のB点 (Fig. 2) であった。両側化あるいは一側 性発作のいずれの群でも意識減損は, 焦点側の側 頭葉の内側構造と外側皮質がともに発作発射に巻 き込まれた後にはじまっていた。また，混合群の 30回の両側化発作に抢いては，意識減損は発作発 射が対側に伝播する以前に明らかに認められた。

\section{2. 一側性発作の臨床特徵}

一側性発作の意識減損の特徵を明らかにするた 
Table 3 Number of patients (seizures) in relation to the side/site of seizure origin presented in 3 groups of patients

\begin{tabular}{l|c|c|c|c|c}
\hline & \multicolumn{4}{|c|}{ seizure origin } & total \\
\cline { 2 - 6 } & $\mathrm{Lm}$ & $\mathrm{Ll}$ & $\mathrm{Rm}$ & $\mathrm{R} 1$ & \\
\hline unilateral group & - & - & $2(13)$ & $3(16)$ & $5(29)$ \\
bilateral group & $4(6)$ & $3(18)$ & $6(28)$ & $2(7)$ & $15(59)$ \\
mixture group & 1 & 1 & 2 & - & 4 \\
(unilateral CPS*) & $(1)$ & $(1)$ & $(3)$ & & $(5)$ \\
(bilateral CPS**) & $(7)$ & $(2)$ & $(21)$ & & $(30)$ \\
\hline
\end{tabular}

* complex partial seizures accompaning unilateral discharges

** those with bilateral discharges

Abbreviations; L, Left; R, right; $\mathrm{m}$, mesial and 1, lateral

Table 4 Number of patients (seizures) manifesting motionless staring (tonic arrest)

\begin{tabular}{l|c|c|c|c}
\hline \multirow{2}{*}{} & \multicolumn{2}{|c|}{ unilateral CPS* } & \multicolumn{2}{c}{ bilateral CPS** } \\
\cline { 2 - 5 } & number & $\%$ & number & $\%$ \\
\hline motionless staring/N & & & & \\
total & $0 / 9(0 / 34)$ & $0(0)$ & $12 / 19(41 / 89)$ & $63(46)$ \\
unilateral group & $0 / 5(0 / 29)$ & $0(0)$ & - & $60(37)$ \\
bilateral group & - & $0(0)$ & $3 / 4(19 / 30)$ & $75(63)$ \\
mixture group & $0 / 4(0 / 5)$ & $0 / 15(22 / 59)$ & \\
\hline
\end{tabular}

Table 5 Mean duration of seizures in 4 patients in mixture group

\begin{tabular}{c|c|c}
\hline case no. & unilateral CPS* & bilateral CPS** \\
\hline 2 & 83 sec. $(\mathrm{n}=1)$ & 94 sec. $(\mathrm{n}=1)$ \\
6 & $73 \quad(\mathrm{n}=1)$ & $102 \quad(\mathrm{n}=2 ;$ range, $84 \sim 119)$ \\
18 & $56 \quad(\mathrm{n}=1)$ & $85 \pm 5 \quad(\mathrm{n}=7 ;$ range, $81 \sim 94)$ \\
21 & $70(\mathrm{n}=2 ;$ range, 53 86) & $103 \pm 34(\mathrm{n}=20 ;$ range, 63 199) \\
\hline
\end{tabular}

めに,すべての両側化発作の臨休像と比較を行っ た。その結果，口部自動症をはじめとする種々の 自動症は, 両側化, 一側性発作の両者に認められ た。しかし，一側性発作では，外来刺激に対する 反応性が部分的であるが保たれて括り，また印象 として発作発射終息後には，検者の指示や問い掛 けに対する反応がょり速やかに回復した。

さらに細かく観察すると, 完全な凝視・無動・ 無反応括よび表情硬直・全身の筋トーヌス充進か らなる特有の停止状態については, 両側化発作で
は 89 発作中 41 発作 $(46 \%)$ に認められたのに対 し, 一側性発作34発作では, 全く認めることはで きなかった。これを混合群 4 症例について検討す ると, 両側化発作では30発作中19発作 $(63 \%)$ 飞 この停止状態を認めたが，一側性発作の 5 発作に は全く認められていない(Table 4)。

さらにこの 4 症例の両側化発作の発作発射の持 続時間を一側性発作と比較した。発作発射が焦点 側に起始してから同じ側で終息するまでの時間を 発作発射の持続時間と定めて計測すると, 両側化 
発作では 63〜199 秒 $(\mathrm{n}=30,98.55 \pm 28.4$ 秒, $\mathrm{SD})$, 一側性発作では, $53 \sim 86$ 秒 $(\mathrm{n}=5,70.2$ \pm 15.2 秒, SD) であり，一側性発作の発射持続は 両側化発作にくらべて明らかに短かった（Table 5)。

\section{考察}

本研究で定義した一側性複雑部分発作とは，側 頭葉起源の複雑部分発作のらち, 一側に起始した 発作発射が終始起始側の側頭葉にとどまり, 対側 の側頭葉に律動性発作波を認めないものである。 このような伝播様式がどのような頻度で観察され るかは明らかでないが， Gloor ら，Munari らは 本研究にみられた伝播様式に相当すると思われる 発作を報告している。Gloor ら $5^{5)}$ にると, 側頭 葉てんかんの14例に慢性深部脳波記録を行い, 72 回の複雑部分発作を捕捉し得たが，5例にみられ た19発作 $(26 \%)$ が一側性複雑部分発作といえる

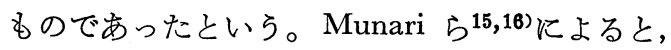
詳細な記述はないが, 数日以内の急性深部脳波記 録で捕捉された52発作のらち，50\%以下に一側性 複雑部分発作がみられたといら。

本研究では一側性群の 5 例に和ける29発作と混 合群 4 例でみられた 5 発作の計 34 発作 (28\%) が 一側性発作であり, Gloor らや Munari らの報告 に和ける頻度と類似している。したがってこの伝 播様式は，むしろありふれたものであるといえ る。

これら一側性複雑部分発作の存在は, 意識減損 の発現に, 発作発射が両側側頭葉を巻き込む必要 のないことを示唆する。しかし意識減損と発作発 射の波及の関連をさらに明らかにするには, 前頭 葉をはじめとする他の脳葉17), さらに上位脳幹レ ベルへの波及7,8,17)を考慮にいれて結論すべきで あろら。

他方, 神経心理学的立場から, 意識減損の発現 には発作発射の拡延によって生じる高次皮質機能 の障害,すなわち認知・言語・記憶・注意などの 障害がかかわる4) とする試論があり, 意識減損に かかわる anatomo-electro-clinical feature を論じ るには多角的な検討を要する。

一側性群と混合群に認めた計34回の一側性発作
を詳細に観察した結果, 意識減損が生起した段階 では, 発作発射が外側かあるいは内側起始かにか かわらず，一側側頭葉の内側構造と外側皮質がと もに発作発射に巻き込まれていた事実を，すべて の発作で確認することができた。をた両側化発作 についても同様に, 起始側側頭葉の内側と外側に 発作発射が伝播した後に意識減損が始まっていた。

Gloor $5^{5)}$ は, 発作発射が一側側頭葉の内側構 造あるいは外側皮質のどちらかに限局していて も，意識減損は起こり得ると述べている。われわ れの結果はこれに一致しない。その理由は頭蓋内 脳波の誘導部位のちがいに帰すことも可能であ る。われわれは, 脳内深部電極と硬膜下電極を併 用した留置法により，発作発射が内側構造にとど まっているか，外側皮質を巻き込んでいるかを正 確に判定することができたからである。

一側性複雑部分発作は, 両側化発作とくらべ て，発作中部分的ながら反応性が保たれている特 徵を示していた。換言すれば一側性発作の意識減 損の程度は, 両側化発作よりも軽く, また発作後 の意識回復は速やかであった。さらに両発作の相 違は, 従来 motionless staring2,3,10), arrest of motion $^{9)}$ と記録されてきた無動・凝視・強直を主 体とする特異な症状が，一側性複雑部分発作では 全く認められなかったといら事実によって，さら に明らかにされた。しかもこの事実は, 混合群に 捕捉された両側化複雑部分発作と一側性複雑部分 発作の比較に扣いても同様に観察され，この症状 の発現が個体差でなく状態差であろらことを示唆 している。われわれは前報で側頭葉起源の複雑部 分発作症状を頭皮脳波から分析し, この無動・凝 視・強直の症状が発作の初期ではなく発作の中期 にみられ, 全般性高振幅徐波律動に一致すること から，側頭葉起源のてんかん性発射が両側の大脳 半球に波及して全般化した時期に和ける反応性低 下を示す発作症状であると結論した6)。本研究で は頭蓋内脳波を用いているとはいえ, 側頭葉に重 点的に電極配備をしているために, 前頭葉をはじ めとする他の脳葉がいかなる役割を演じているか は明らかにし得ないが，無動・凝視状態が起こる ための条件の一つに, 少なくとも両側の側頭葉が 発作過程に巻き込まれる必要があることが確認さ 
れた。また Escueta らは，無動・凝視状態の出現 に関連する部位として，Bender の見解)を採用し て, 中脳部の関与を推定している。この推論が正 しいとすれば，両側化複雑部分発作では，中脳部 まで発作発射が伝播しているのに対し，一側性複 雑部分発作では，この領域まで伝播が及んでいな いといら仮説が成り立つであろう。

さらに発作発射の持続時間を, 混合群に限って 両側化発作，一側性発作の間で比較したところ， 一側性複雑部分発作の持続時間はより短かった。 ちなみにこの混合群 4 例のうち 3 例で捕捉された 計27回の単純部分発作の持続時間は平均60秒であ り, この值は混合群に認めた一側性発作の平均70 秒に近いものであった。持続時間が短いことは, 一側性複雑部分発作の特徵であるものの, 意識減 損発現と発作発射持続時間との関連はなく，単純 部分発作との差は一側側頭葉内でのてんかん発射 の拡がりの違いである可能性を示唆するものと思 われた。

\section{文献}

1) The commission on classification and terminology of the international league against epilepsy (1981) Proposal for revised clinical and electroencephalographic classification of epileptic seizures. Epilepsia 22, 489-501.

2) Escueta, A.V., Kunze, U., Waddell, G., Boxley, J., Nadel, A.(1977) Lapse of consciousness and automatisms in temporal lobe epilepsy: a videotape analysis. Neurology 27, 144-155.

3) Escueta, A.V. (1985) Type 1 Complex partial seizures of hippocampal origin: excellent result of anterior temporal lobectomy. Neurology 35, 143-154.

4) Gloor, P.(1986) Consciousness as a neurological concept in epileptology: a clinical review. Epilepsia 27, s 14-s 26.

5) Gloor, P., Olivier, A., Ives, J. (1980) Loss of consciousness in temporal lobe seizures: observations obtained with stereotaxic depth electrode recordings and stimulations. In: Advances in Epileptology (Canger, R., Angeleri, F., Penry, K. ed.), 349-353, Raven Press, New York.

6) 日吉俊雄, 牧野吉真, 宮越雅子, 八木和一, 清野 昌一(1985)側頭葉てんかんの自動症一発作症状 脳波関連からみた症候論一，てんかん研究 3,97-
107.

7) Jasper, H.H. (1962) Mechanisms of epileptic automatism. Epilepsia 3, 381-390.

8) Jasper, H.H. (1964) Some Physiological mechanisms involved in epileptic automatisms. Epilepsia 5, 1-20.

9) Lennox, W.G. (1960) Epilepsy and Related Disorders, Little-Brown, Boston.

10) Maldonado, H.M., Escueta, A.V., Walsh, G.O., Swartz, B.E., Rand, R.W. (1988) Complex partial seizures of hippocampal and amygdalar origin. Epilepsia 29, 420-433.

11) Mihara, T., Matsuda, K., Tottori, T., Watanabe, Y., Yagi, K., Seino, M. (1987) Combined implantation of intracerebral and subdural electrodes for long-term recording in temporal lobe epilepsy. 17 th Epilepsy International Congress, Jerusalem.

12) Mihara, T., Matsuda, K., Tottori, T., Watanabe, Y., Yagi, K., Seino, M. (1988) Experiences in chronic depth EEG recording of 23 cases with intractable temporal lobe epilepsy. Jpn J Psychiat Neurol 42, 571-573.

13）三原忠紘, 鳥取孝安, 清野昌一 (1985) 複雑部分 発作の脳波所見 (I)．臨床脳波 27，805-813.

14）三原忠紘, 鳥取孝安, 清野昌一 (1986) 複䧴部分 発作の脳波所見 (II). 臨床脳波 28, 53-64.

15) Munari, C., Bancaud, J., Bonis, A., Stoffels, C., Szikla, G., Talairach, J. (1980) Impairment of consciousness in temporal lobe seizures: a stereoelectroencephalographic study. In: Advances in Epileptology (Canger, R., Angeleri, F., Penry, K. ed.), 111-114, Raven Press, New York.

16) Munari, C., Stoffels, C., Bossi, L. et al. (1982) Partial seizures with elementary or complex symptomatology: a valid classification for temporal lobe seizures? In: Advances in Epileptology (Akimoto, H., Kazamatsuri, H., Seino, M., Ward, A. ed.), 25-27, Raven Press, New York.

17) Penfield, W., Jasper, H.H. (1954) Epilepsy and Functional Anatomy of Human Brain. LittleBrown, Boston.

18) Wada, J.A., Rasmussen, T. (1960) Intracarotid injection of sodium amytal for the lateralization of cerebral speech dominance: experimental and clinical observation. J Neurosurg 17, 266282. 


\section{Summary}

\section{Complex Partial Seizures with Unilateral Discharges Originating from Temporal Lobe}

Hironari Sue, Toshio Hiyoshi, Tadahiro Mihara, Kazumi Matsuda, Takayasu Tottori, Nobuyuki Kishi, Yutaka Watanabe, Kazuichi Yagi, Masakazu Seino

A clinico-electrographic correlative study was carried out to explore whether ictal involvement of bilateral temporal lobes is indispensable for complex partial seizure(CPS). The subjects consisted of $123 \mathrm{CPSs}$ of 24 patients documented by chronic intracranial EEG recordings which were performed as a presurgical evaluation of intractable temporal lobe epilepsy.

In the majority of CPSs (89 CPSs, 72\%), selfsustained rhythmic discharge involved bilateral temporal lobes; however, in the remaining $34 \mathrm{CPSs}$ (28\%), it remained unilateral to the originating side throughout the CPSs. Although bitemporal ictal involvement was not necessary for impairment of consciousness, both mesial (amygdala and hippocampus) and lateral (cortex) temporal lobe structures were consistently involved.

In comparison with the CPSs with bilateralized discharges, those with unilateral ones were characterized as follows: 1) responsiveness to external stimuli was partially retained, 2) postictal recovery of consciousness was more prompt and 3) motionless staring characterized by total unresponsiveness was never observed.

Based on these findings, the mechanisms underlying impairment of consciousness of CPS was discussed in association with a functional linkage between temporal lobe and brain stem.

J. Jpn. Soc. $1991 ; 9$ : 54-62

(received: December 1, 1990, accepted: January 14, 1991) 